Is this need for manliness and love common to America in general? In his novels, Baldwin implies that it is. But the issue is unimportant to those Black dramatists who focus on the problems of love among Blacks. Is there overemphasis on the absence of love in Black communities? Perhaps. Nikki Giovanni suggests that possibility when, in "Nikki-Rosa," she argues that sociological biographies of Blacks fail to observe the power of love within Black families. Is there no need to picture Blacks who live outside the urban-Northern ghetto? Certainly, the Black playwrights of the past decade have ignored them. One can say only that, at this time, Black dramatists are not answering these questions. Presently, whether they propose realistic portraiture for the artistic entertainment of audiences which may be White or whether they propose realistic portraiture for Black audiences, the best-known Black playwrights are picturing an urban Northern community which is disparate from the White community and which is populated by those who need but lack the strengths which come from love.

\title{
NOTES
}

1 Take a Giant Step, in Black Drama in America, Darwin T. Turner, ed. (Greenwich, Conn.: Fawcett, 1971), Act II, Sc. 1, p. 346.

2 A Raisin in the Sun (New York: Signet/New American Library, 1966), Act II, Sc. 3 , p. 97.

3 Hansberry, op. cit., Act III, p. 128.

4 Hansberry, op. cit., Act III, p. 125.

5 Dutchman, in Dutchman and The Slave (New York: Morrow, 1964), p. 35.

6 Ernst Toller, "Post-War German Drama," The Nation, 127 (November 7, 1928), p. 488.

7 Great Goodness of Life: A Coon Show, in Four Black Revolutionary Plays by LeRoi Jones (Indianapolis: Bobbs-Merrill, 1969), p. 58.

8 Ain't Supposed to Die a Natural Death (New York: Bantam, 1973), p. 73.

9 Van Peebles, op. cit., p. 45.

DRAMA / SARAH WEBSTER FABIO

\section{Saga of the Black Man (A Pageant-Drama)}

[Sarah Fabio's pageant-drama exemplifies the manner in which contemporary Afro-American playwrights blend Black cultural tradition with innovation. Structurally, the drama continues the tradition of the historical pageant, a form more frequently used in Black theater than in modern American theater as a whole. Always intended for a Black community audience, the pageant, created by such Blacks as Langston Hughes, W. E. B. 
Du Bois, and LeRoi Jones, does not imitate the well-made-play structure of initial situation, rising action, climax, and dénouement. Instead, mixing historical with fictional characters and incidents, the dramatist, by means of episodic vignettes, sweeps the audience from the historical past of Blacks to a climactic present. In the final scenes, Sarah Fabio shapes the traditional pageant into the form of contemporary Black Arts theater. In the penultimate scene, she pronounces the message/theme characteristic of Black Revolutionary drama, and in the final scene, she affirms Black communality in the manner characteristic of Black Ritual drama. (D.T.T.)]

\section{Acr I}

The Golden Glorious Dark Age (11th-Century Timbuctu)

Risers forming platform for musicians and dancers upstage center-right; right downstage fruit vendors, mostly women; children buying fruit and skipping through the crowd. In the center at the right end of the platform two or three artists with their wares, backdrop showing walls, a mosque tower, a university compound. At stage left a stand with cloth, hats, beads, dishes, with vendors and customers, using cowrie shells and barter as means of exchange. Stage should bustle with activity; about twenty performers. An old turbaned man, a story teller, is seated on the platform at first, with a small group gathered around him.

1st Man: A story, a story.

All: Yes, Old Man, a story.

Old Man: If the father has eaten sour grapes, shall the son's teeth be set on edge?

1st Man: Let it go from thee.

All: Let it return.

Old Man: It is not possible to say in which town this occurred but, know you, it is not this town nor any other town near here, but it did occur and in a town like this one. (HIS VOICE IS DROWNED BY OTHER NOISES)

("GLIMPSES" A POEM, OR A FOLKLORIC TALE SUCH AS "THE TALKING SKULL” CAN BE INSERTED HERE.)

1st Vendor: Buy tender okra, ripe mango; buy my fresh goobers.

2nd Vendor: Yams, yams, tender yams, sweet yams; yams, yams. 
Young Boy: Here are twenty cowries; I'll buy a mango; I'll buy two mangoes. Here. (HE TAKES FRUIT, SHARES WITH HIS GIRL COMPANION AND WEAVES THROUGH THE CROWD)

\section{(AT STAGE LEFT A MAN AND TWO SONS AND HIS WIFE)}

2nd Man: Two hats to shade the sun from the heads of my beloved sons. And beads, fine beads for my wife. (HE GIVES THE HATS TO HIS SONS, WHO IMMEDIATELY TRY THEM ON. HE PLACES THE BEADS AROUND HIS WIFE'S NECK AND STANDS BACK APPROVINGLY. HE THEN PULLS OUT HIS PURSE: THIS SCENE FADES INTO PANTOMIME WITH FINGERS AND HEADSHAKES UNTIL THE PRICE IS REACHED, THEN A HANDSHAKE TO SEAL AGREEMENT AS THE GROUP MOVES TOWARD THE CENTER STAGE)

(THREE STUDENTS ENTER STAGE RIGHT: TWO ITALIANS AND ONE AFRICAN)

1st Italian: Timbuctu, Timbuctu, a dream come true. Just think, two years at the University of Sankore in one of the most famed cities in the world.

African: And home for me. How I missed it when abroad! There is more hustle and bustle here per square inch than in a town square in Rome. (THEY LAUGH)

2nd Italian: I must try to keep my mind on my studies. The University medical course is well known for its rigors.

1st Italian: The finest minds in medicine are right here behind those walls. And we'll have the privilege of studying with them.

2nd Italian: However, I shall render unto Caesar only that which is his due. There are other wonders here, I am told. (THEY LAUGH)

1st Italian: Why else would a Latin leave Rome, I ask you? (THE MUSICIANS BEGIN TUNING UP; DRUMS SWELL THE AIR)

African: The finest artists in the world. Such woven fabrics as are the envy of the world. Golden bracelets that catch the eye of the most aloof woman and make her dance for you and you alone. (HE LOOKS ABOUT AS CROWD GATHERS IN A CIRCLE AROUND THE CENTER RISER WHERE PERFORMERS ARE. PEOPLE SIT ON THE GROUND IN 
THE STREET. HE GENTLY PUSHES THE TWO VISITORS FORWARD.) But come. The festivities are about to begin.

1st Vendor: Mangoes, mangoes, goobers, okra, mangoes, ripe mangoes.

2nd Vendor: Yams, yams, juicy sweet yams. Buy yams today. (VENDORS STAY WHERE THEY ARE; SOME WOMEN SHOULD HAVE BUNDLES ON THEIR HEADS AND THEY JOIN IN CLAPPING HANDS AND GAZE TOWARD THE STAGE. MUSICIANS AND DANCERS HAVE THE STAGE. LIGHTS TURN RED, BLUE, AND FADE.)

\section{CURTAIN}

\section{Acr II}

SLAVE TRADE-FOUR CENTURIES: 20 MILLION SOULS; MUTINY ON THE AMISTAD, 1839

\section{SCENE I}

"IN THE HOLD OF THE AMISTAD"

(ACTION DIVIDED INTO FOUR SCENES ACCORDING TO LOCATION ON STAGE. FIRST ACTION TAKES PLACE IN THE HOLD OF THE SHIP, SPOT ON STAGE RIGHT WITH REDS, BLUES: UPSTAGE RIGHT)

DRUMS-AS THE SCENE IS OPENED THE STAGE IS DARK AND ONLY VOICES ARE HEARD; MOANS, GROANS, PUSHING SOUNDS, CHAINS RATTLING, WEEPING, SCREAMS, BODIES BUMPING ABOUT.

1st Man: Ooooh, Shango, Shango, save us, save us. Aaaeeeiii . . Ooooooh ... Ohhhh.

1st Woman: My child, my child. She is so sick ... She die ...

2nd Woman: Take these chains ... Take these chains ... Set us free ... Set us free.

1st Man: Shango, Shango, save us ... Save us ... Shango ...

2nd Woman: My man, I see you no more ... No more, my man ... My man gone ... My child ... Gone ... My home ... Gone ... Oooaah. 
2nd Munt: Air . . I can't breathe ... I die ... I die ... Aaaiiiieeee ...

3rd Man: Save me, God ... My God ... Why hast thou forsaken me ...?

3rd Woman: Oooooh ... Ooooooh ... My baby ... My baby ... She is so sick ... She die ... Push ... Push ... Break these chains ... Break these chains ... We die... We die...

1st Man: Shango, Shango, Save us ... Shango, Shango, Shango, save us ... Oooooaaaaahh ... OOOOaaaaahhhh.

SCENE II

VOICES FUSE INTO A HUM WHICH RISES IN CRESCENDO, THEN DIES OUT. SPOTLIGHT FIXES ON GROUP AT DOWNSTAGE LEFT. THE MEN ARE PASSING AROUND A FLASK. THE CAPTAIN HANDLES IT MORE BRUSQUELY THAN DO THE OTHER MEN. HE RETURNS THE FLASK AND WIPES HIS MOUTH WITH THE BACK OF HIS HAND.

RED AND BLUE LIGHTS REMAIN FIXED ON THE SCENE IN THE HOLD DURING THE 1ST SCENE ON DECK. THE BODIES IN THE HOLD ARE CHAINED TOGETHER VERY CLOSE, BACK TO BACK; AT LEAST TWELVE BODIES-WEAVING, ROCKING, THRASHING ABOUT, STRAINING AGAINST CHAINS, COUGHING, STRANGLING, SUFFOCATING, WEEPING, STRUGGLING, WEAKENING, DYING.

(DIM LIGHTS FOCUS ON HOLD AT STAGE RIGHT; SPOT STAGE LEFT; FADE RIGHT. CAPTAIN AT THE STERN; TWO SPANISH GENTLEMEN ON DECK)

1st Gentleman: How those black cries cloud the clear night. Many were torn from their loved ones in Havana.

2nd Gentleman: They'll calm down after a day or two. Wretches!! They're lucky to be alive from all I've heard.

Captain: Luck!!! By God, you're right!! Don't you mind. We'll reach Porto Principe with a fine cargo of black gold, Señors.

1st Gentleman: The factor who was aboard ship on this voyage from Sierra Leone warned that the worst of those left ashore in Havana to be broken in 
were a rebellious sort of blacks. Much of the trip across, they refused food; killed loved ones at every opportunity; and sent forth daily prayers for death to their God, Shango.

2nd Gentleman: Whose?? Ours or theirs??

Captain: Good question. Those slaves carry with them the stench of death. Last night we passed a ghost ship, not a living soul aboard, mind you. The plague, it seems. Only last week another schooner drifted by; we boarded her only to find crew and cargo blinded by ophthalmia, not even the pilot could see a blasted thing. Drifting, just drifting.

1st Gentleman: Still. It gives me the creeps.

Captain: Before I owned my own schooner, I sailed aboard a slaver. Made ten trips to Africa, running raids along the coast. Sometimes as many as $\mathbf{5 0 0}$ black devils would be aboard. By Gawd, that's bedlam, all right.

2nd Gentleman: After this we'll be seasoned ... Captain, or mad ...

SCENE III

ON DECK, TOP OF STAIRS ABOVE HOLD

THE THIRD SCENE TAKES PLACE STAGE CENTER; SPOTLIGHT

THE ACTION.

(VOICES IN THE HOLD GET LOUDER. THE FIRST GENTLEMAN PASSES AROUND A FLASK AND THE THREE VOICES ARE RAISED IN A GOOD NATURED ROUND OF LAUGHTER. VOICES DIM AS A SPOT IS FOCUSED ON CENTER STAGE. RISERS TO SUGGEST STAIRS. TWO MEN: ONE WITH BROKEN CHAINS WITH A KEY UNLOCKING THE OTHER)

Slave: Cinque, my prince, hurry! Free me. My wife, my three daughters are at the mercy of those drunken sailors!

Cinque: Quiet. Soft, now; it's almost done. The arms are in the galley; I've taken care of the cook. The sailors are defenseless; unarmed and in a drunken stupor.

Slave: There, my good Cinque; it's done. What would you have me do? 
Cinque: Free the men, women; overtake the sleeping sailors and bring them on deck. The rest of you men, follow me.

Slave: We kill the white devils!!!

Cinque: Do as I say!! Bring them on deck!! We will set them adrift. Tell my people their Prince commands them to do this.

Slave: Yes, my Prince.

Cinque: Use this marlinspike if need be. I will take care of the Captain. Then, we'll head this schooner East and return home to Africa.

Slave: Even if we reach Nassau, the English port, we will be free!

Cinque: I am the son of a Mandi chief; I will be free! Go below; when you are done, assemble on deck. Soon we'll be on our way to Lemboko. Warriors, come with me. Soft now.

\section{SCENE IV}

(CINQUE AND MEN OVERTAKE MEN ON THE DECK; CINQUE'S BLOW FELLS CAPTAIN; THE OTHER TWO MEN ARE ROUGHED UP AND TIED TO POSTS; THE CAPTAIN IS TIED TO A STAKE, UPRIGHT, STILL, SEEMINGLY AT THE STERN. . . . LIGHT FADES CENTER, SPOT LEFT)

1st Gentleman: But I am at your mercy. Spare my life; I'll do whatever you wish.

Cinque: I'll release you. (TO MUTINEERS) Release this man. (TO THE FIRST GENTLEMAN) Your life is at stake. Turn this schooner around. My people and I wish to be back home. Back to Africa.

All: Africa!!!! Africa!!! Home to Africa!!!

SCENE V

(AUCTION BLOCK, BOSTON, MASS., 1761)

(A SLAVE BLOCK IS REVEALED AS THE REAR TRAVELER IS OPENED. A SLAVE WOMAN IS SHACKLED BY THE WRISTS; A 
MAN HAS A BALL AND CHAIN AND HANDCUFFS. PHYLLIS SITS ON THE BLOCK, PASSIVELY, WHILE THE WOMAN WRESTLES TO FREE HERSELF.)

Auctioneer (VOICE HEARD OFFSTAGE): Do I hear another bid? $\$ 3,000.00$. Step up and feel these biceps. See those muscles flex. $\$ 3,400.00$. With one man like this you can breed a whole plantation of slaves. Do I hear another bid? Going, going, gone.

Slave Man: If only I could break these chains!

Phyllis (TO THE WOMAN): Do stop struggling to free yourself. We'll get the whip again.

Slave Woman: Oh, I'd rather be beat to death than suffer a slow death like this. The torture! You're too young to know what it means to be sold like cattle.

Phyllis: Today it will be done. May our masters have mercy and be kind!

Slave Man: We're being sold like cattle and we'll be treated like cattle, or worse.

Slave Woman: Oh wretched me! Yesterday, a merchant with a husband, children, a home, land; now nothing. And you, child, what about you?

Phyllis (STAMMERING): I don't know. Yesterday is a dream . . . I see a village, faces of my tribesmen, but so faraway. Then, clearly I see my mother's face with the early sun warming it. She stands outside the hut pouring water from a pitcher. Every morning the same ... I'm so thirsty, so cold, so alone.

Auctioneer: Look lively now. (HE CRACKS THE WHIP AT THE GIRL'S FEET. HE STRIKES THE MAN.) Be still. I don't want any chain burns.

(SUSANNAH AND JOHN WHEATLEY COME ON STAGE AND APPROACH THE AUCTION BLOCK.)

Susannah: I wish there was some other way to get help, John. I despise this traffic of humans.

John: We've been over this many times before, Susannah. Now make up your mind. Do you have a preference? 
Susannah: What I need is a good worker; the chores are out of hand. This one looks good and strong. (GLANCES TOWARD THE SLAVE GIRL.) My, John, look how that small thing shivers!

John: It'll be years before you get a good day's work out of her.

Susannah: She may be a bargain.

Auctioneer: Here's a strong wench for you. Spirited she is; plenty energy. Built like an ox, a Dahomey "Amazon." Opening bid on this one is $\$ 2,000$.

John: How much for the small one?

Auctioneer: You don't want her. Now take this ...

John: How much?

Auctioneer: Well, I don't know. She's puny but young and with a good build. Fatten her up and she might be all right. Let's take a look. (HE REACHES FOR PHYLLIS AND SHE PULLS AWAY.)

John: Never mind that. I'll take her. Send me a bill of sale. Come along, girl. Keep yourself covered. (WALKING BRISKLY ACROSS THE STAGE AND EXITING UPSTAGE RIGHT.)

Susannah (HOLDING OUT A HAND TO HER; THE GIRL FOLLOWS HER): There. You poor thing, you're trembling. You'll catch your death, child. Come. What are you called? Don't be afraid. I'll call you Phyllis. Phyllis Wheatley. Don't hold back. You'll be treated in a Christian manner. Come along. (THEY EXIT SLOWLY AS SHE WALKS IN THE SAME DIRECTION AS JOHN.)

(THE SLAVE BLOCK WITH THE SHACKLED SLAVE WOMAN AND THE AUCTIONEER BECOMES A STILL SCENE AS THE LICHTS DIM AND GO OUT.)

AcT III

Sunday Insurrection

Nat Turner Slave Revolt-August, 1831

(CURTAINS OPEN ON A BAPTISMAL SERVICE IN THE WOODS BY THE BANK OF A RIVER. STAGE LEFT HAS ABOUT TWENTY 
STRAIGHT-BACK CHAIRS ARRANGED WITH A CENTER AISLE BETWEEN THEM: A PODIUM IS UPSTAGE. REV. NAT TURNER IS FINISHING HIS SERMON AS THE SCENE OPENS. ON THE FRONT SEAT IS A WHITE FAMILY-MAN AND WIFE AND DAUGHTER WHO HAVE COME FOR BAPTISM. TWO BLACK WOMEN ARE ALSO BAPTIZED. THE CHURCH IS FILLED WITH SLAVES; SOME WEAR THE DISCARDED CLOTHES OF THEIR MASTERS. FIVE MEN ARE DRESSED IN WHITE DUCKS WITH RED HANDKERCHIEFS AROUND THEIR NECKS. THE AUDIENCE ROCKS TO AND FRO AND RESPONDS TO THE SERMON.)

Nat Turner (AT THE PODIUM): There are bad times and there are bad people, and when people get better, one by one, the times will get better for all.

Audience: Yes, Lord.

Nat Turner: God doesn't love wickedness. Soon one day He will stay the oppressor's hand.

Audience: Yes, He will. He sho' will.

Nat Turner: He will call His servant like Moses did of old and say, "Go down, Moses, way down into Egypt land; tell old Pharoah to let my people go."

Audience: Yes, Lord. He’p us, Jesus.

Nat Turner: Yes, and they will let my people go. Yes, soon. Listen as I tell you, brothers, soon; that promised land will be ours, forever.

Audience: Yes, Lord, we're bound for the promised land. Teach, Rev. Turner.

Nat Turner: Times will get better when people get better. You may be a plowman at Turner's mill, a tidewater fieldhand, Marse Samuel's house servant, the only two-legged chattel at Shiloh, a witness in Babylon, but you can serve your Lord because He's with you ever where you go.

Audience: Yes, He is; Jesus is with us.

Nat Turner: During my darkest trials, I call the Lord . . Lord, are you 
there??? And he sends a sign on the bright air. I am with you, my servant. I abide. I abide.

This morning we've baptized the good Pemberton family from Sussex. The Lord is pleased this morning.

Audience: Praise God.

Nat Turner: He wants white folks to get better just like He wants black folks to get better.

Audience: Yes, He do.

Nat Turner: Sister Ada and Sister LouAnn joined the band of God's chosen people this morning. As we leave here this morning, I want you to lift your voices high in song ... "Jerusalem ... Jerusalem, lift up your voice and sing. Hosannah, in the highest, Hosannah forevermore."

\section{All (SINGING; REPEAT SEVERAL TIMES)}

Nat Turner: Will the deacons remain seated after the sermon; we'll have a short deacons' meeting. The hour is nigh when we will march on to Jerusalem. (VOICE RISING IMPASSIONATELY AND LYRICALLY) Oh, won't you come go with me; I'm bound for that promised land.

(REV. TURNER WALKS TO THE LAST ROW LEADING THE OTHERS SINGING “JERUSALEM." RIGHT BEHIND HIM ARE THE PEMBERTONS. THE NEWLY BAPTIZED ARE IN WHITE ROBES. THEY FOLLOW THE PEMBERTONS. REV. TURNER TURNS TO SHAKE THE HANDS OF THE CONGREGATION. FIVE MEN WITH RED HANDKERCHIEFS AROUND THEIR NECKS ARE LEFT SEATED.)

Mr. Pemberton: Rev. Turner, you've set my soul afire today. I want to thank you for helping to show me the light of Jesus.

Mrs. Pemberton: The family is mighty happy you seen fit to baptize us. You have the name around these parts of having the power of the Holy Ghost.

Nat Turner: I'm pleased to do the Lord's will. I got a calling; and I have answered it as I see fit. 
Mr. Pemberton: It's such a lovely, warm evening, I told Matilda we'd have our Sunday spread here in the woods a bit.

Nat Turner: Yes, glory in God's goodness while there is still time.

Mr./Mrs. Pemberton: Good day, Rev. Turner.

(HE SHAKES HANDS BRIEFLY AS OTHERS LEAVE. THEN HE TURNS AND GOES DOWN FRONT TO SPEAK TO THE FIVE MEN.)

Rev. Turner: I see the sign that you're ready today to answer God's call. We're going to steal away from here and walk into Jerusalem just like John. Soon we will be done with the trouble of this world.

All: Amen. Amen.

Rev. Turner: Clear the path before your feet. Don't leave a stone unturned. Spread the word and gather unto you the host and multitude; well meet again at Shiloh and then on to Jerusalem. Is that clear?

All: Praise God. We're on our way. Lord, Lord, don't abandon us in the hour of our great need.

Rev. Turner: The Lord is with us and our spirit. Blessed be the name of the Lord. Today, I will twice deliver the Pembertons; once into the glory of the Lord, and once into the bosom of the Lord. And now, "Steal away, Steal away, Steal away to Jesus. Steal away, Steal away home. I ain't got long to stay here."

$A l l$ (LEAVING AND SINGING)

(THE PEMBERTONS HAVE SPREAD A CLOTH AND ARE HAVING A PICNIC AT STAGE RIGHT.)

Matilda: Don't you just love to hear those darkies singing? It makes everything so peaceful like.

Mr. Pemberton: Praise be to God for the Southampton Nigras . . . What's that!!!? AAAEEEIII ...

(THE BAND OF MEN OVERTAKE THEM. MUFFLING THEIR CRIES, IHEY DRAG THEM FROM THE STAGE, UPSTAGE RIGHT. THE SONG CONTINUES AS THE STAGE GOES BLACK.) 


\title{
CURTAIN
}

\author{
Act IV \\ Men of Color, to Arms-Civil War, 1863
}

(CURTAIN CLOSED. FREDERICK DOUGLASS ENTERS STAGE LEFT AND CROSSES TO STAGE RIGHT; STANDING AT THE PODIUM ASSUMES THE POSE OF ORATOR.)

Douglass: From East to West, from North to South, the sky is written all over, NOW OR NEVER. Liberty won by white men would lose its luster. Who would be free, themselves must strike the blow. Better even die free, than to live slaves. This is the sentiment of every brave colored man amongst us. . . . Remember Denmark Besey of Charleston; remember Shields Green and Copeland; remember Nathaniel Turner of Southampton. Remember those brave black youths of Oberlin who followed noble John Brown and fell as glorious martyrs for the cause of the slave. Remember that in a contest with oppression, the Almighty has no attribution which can take sides with oppressors.

\section{CURTAIN OPENS.}

(MAJOR MARTIN DELANEY STANDING DOWNSTAGE, LEFT, WITH A CUP OF COFFEE. HIS UNIFORM HAS SASH AND SABER. MEN SEATED AROUND BONFIRES. THEY SING WITH HEAVY EFFORT. RED AND BLUE LIGHTS FLICKER, SHOWING BACKDROP IN THE BACKGROUND, WHICH IS THE BATTLEGROUND.)

\section{(SINGING)}

All: Mine eyes have seen the glory of the coming of the Lord; He is trampling out the vintage where the grapes of wrath are stored; He hath loosed the fateful lightning of his terrible swift sword; His truth is marching on. Glory, glory, hallelujah; Glory, glory, hallelujah; Glory, glory, hallelujah; His truth is marching on.

\section{(VOICES TRAIL OFF INTO A HUM.)}

(ROBERT SMALLS ENTERS STAGE RIGHT WITH CONTRABANDS PARTLY CLOTHED WITH CASTOFF CLOTHES, CROCUS BAGS, BLANKETS WITH ARMHOLES FOR JACKETS, HANDKERCHIEFS ON THEIR HEADS, PANTS TIED BELOW AND ABOVE THE KNEE AND AT THE WAIST TO KEEP THEM ON. WOUNDED SOLDIERS 
ARE SUPPORTED AND PLACED ON THE GROUND, SOME ARE CARRIED ON LITTERS. WITH THEM IS HARRIET TUBMAN WITH A SKIRT, OVERCOAT, AND CARRYING A RIFLE. SHE BUSIES HERSELF WITH THE WOUNDED.)

Sergeant (SEES THEM AND CROSSES OVER. HE SALUTES THE COMMANDING OFFICER.)

Robert Smalls (SALUTING): Robert Smalls, United States Navy, reporting to Major Martin Delaney, 104th Regiment.

Sergeant: Yes, sir. Come with me, sir.

\section{(THEY WALK OVER TO MAJOR DELANEY.)}

Sergeant: Major Delaney, Robert Smalls, United States Navy.

Major Delaney: So you are the famous Mr. Smalls-a legend here in Charleston. I believe it was the Confederate steamer-the Planter-which caused your fame.

Robert Smalls: Yes, sir. With the help of my brother, John, in 1862 we delivered the Confederate Planter to the Union forces.

Major Delaney: Yes, and won a good-size purse as well as fame.

Robert Smalls: Yes, sir. Thank you, sir. Major Delaney, I have orders to deliver 45 contrabands who wish to join the Union Army. Also 15 men from the 54th Mass. Colored Regiment who are badly in need of care and separated from their men. When I came upon them they were being treated by Harriet Tubman. She asked that they be brought to you. Your doctoring is as highly recommended as your soldiering, sir.

Major Delaney: My good friend Harriet Tubman. They are in good hands. A fine nurse.

Robert Smalls: And an able scout and intelligence agent.

Major Delaney: So she is. You may wish to rest and eat. Such as we have we are happy to share.

Robert Smalls: Thank you, sir. 
THE SERGEANT AND THE DISPATCHER ARRIVE FROM STAGE RIGHT. THE DISPATCHER CARRIES A MAIL POUCH OVER HIS SHOULDER.

Sergeant: A dispatcher from Washington, Major Delaney. He wishes to have a word.

Dispatcher: Major Delaney, an important dispatch from Washington, from President Lincoln. If you will assemble your men, I'll read it publicly.

Major Delaney: Attention, men, a dispatcher from Washington, from President Lincoln.

Dispatcher (READING) : From the President of the United States of America, the Emancipation Proclamation:

Whereas on the 22nd day of September, A.D. 1862, a proclamation was issued by the President of the United States, containing among other things, the following, to wit:

That on the 1st day of January, A.D. 1863, all persons held as slave within any state or designated part of a state the people whereof any shall be then, thence forward, and forever free; and the executive government of the United States, including the military and naval authority thereof, will recognize and maintain the freedom of such persons and will do no act or acts to repress such persons, in any efforts they may make for their actual freedom...

Now, therefore, I, Abraham Lincoln, President of the United States, by virtue of the power vested in me as Commander in Chief of the Army and Navy of the United States, and in times of actual armed rebellion against the authority and government of the United States, and as a fit and necessary war measure for suppressing said rebellion, do, on this 1st day of January, A.D. 1863, all in accordance with my purpose so to publicly proclaim for the full period of one hundred days from the first day above mentioned, order and designate as the States and parts of States wherein the people thereof, respectively, are this day in rebellion against the United States the following writ:

Arkansas, Texas, Louisiana .. . Mississippi, Alabama, Florida, Georgia, South Carolina, North Carolina, and Virginia (except the forty-eight counties designated as West Virginia ....)

And by virtue of the power and for the purpose aforesaid I do order and declare that all persons held as slaves within the said designated States and parts of States are, and henceforth shall be free; and that the Executive Government of the United States, including the military and naval thereof, 
will recognize and maintain the freedom of said persons. And I hereby enjoin upon the people so declared to be free to abstain from all violence . . . unless in necessary self-defense; and I recommend to them that, in all cases when allowed, they labor faithfully for reasonable wages.

And I further declare and make known that such persons of suitable condition will be received into the armed service of the United States to garrison forts, positions, stations and other places, and to man vessels of all sorts in said service.

And upon this act, sincerely believed to be an act of justice, warranted by the Constitution upon military necessity, I invoke the considerate judgment of mankind and the gracious favor of Almighty God.

All (CLAPPING HANDS, SHOUTING, HUGGING EACH OTHER; THE CONTRABANDS AND THE BLACK SOLDIERS SING):

Free at last, free at last,

I thank God I'm free at last.

Free at last, free at last,

I thank God I'm free at last.

(HARRIET CROSSES OVER TO STAGE LEFT AND TO MAJOR DELANEY. VOICES BECOME A HUM.)

Harriet: Major Delaney, come quick!! One of the soldiers needs help badly.

Major Delaney (SHAKING HANDS, GRABS HIS MEDICAL KIT AND CROSSES STAGE, ROLLING UP HIS SLEEVE): Harriet, my good friend, I can use you around here. (HE KNEELS BESIDE THE SOLDIER; FEELS, WITHOUT SUCCESS, HIS PULSE; LETS HIS HANDS DROP AND PULLS THE SHEET OVER HIS FACE. HE THEN WALKS AROUND THE LITTERS, CURSORILY EXAMINING THE OTHERS.) My God, these men look like they've had a bad time!!

Harriet: Yes. I was there. I saw it all.

Major Delaney (LOOKING UP COAXINGLY): Yes, yes, go on.

(HARRIET WALKS BETWEEN THE LITTERS, ABSENTLY. SOLDIERS HUM SOFTLY THE FIRST STANZA TO "BATTLE HYMN OF THE REPUBLIC.” AS SHE FINISHES, THEY SING AS LIGHTS FLASH RED AND BLUE AND BATTLE NOISES RESUME.) 
Harriet: And then we saw the lightning, and that was the guns; and then we heard the thunder, and that was the big guns; and then we heard the rain falling, and that was the drops of blood falling. And when it came time to get the crops, it was the dead men that we reaped.

(SHE STANDS LEANING AGAINST HER RIFLE, STAGE CENTER. MAJOR DELANEY KNEELS BESIDE A MOANING SOLDIER, BANDAGING HIS LEG. THE SOLDIERS AT THE STAGE LEFT ARE STANDING WITH HANDS OR HATS AT THEIR HEARTS IN A PATRIOTIC GESTURE.)

All (SINGING):

... He hath loosed the fateful lightning of his terrible swift sword;

His truth is marching on.

Glory, glory, hallelujah! Glory, glory, hallelujah!

Glory, glory, hallelujah! His truth is marching on!!

\section{CURTAIN}

Act V

First Annual Convention

August 2, 1920

Universal Negro Improvement Association Lineup and Costumes

African Legion-Dark blue uniforms with narrow red trouser stripes, unarmed except for dress swords worn by officers.

Black Star Nurses-White attire; long white choir gowns.

African Chief

(SCENE OPENS IN FRONT OF PROGRESS PAPER MILL WHICH HAS BEEN CLOSED DOWN IN NEW YORK. THERE ARE A GROUP OF WHITE PICKETS AND, OPPOSING THEM, A CROWD OF NEGRO WORKERS-SCABS FOR THE MOST PART. LATER, THE GARVEY PARADE ENTERS STAGE LEFT, MOVES ACROSS THE STAGE TO DOWNSTAGE RIGHT, WHERE A RISER WITH ROPES CREATES A PLATFORM FOR GARVEYS SPEECH. STAGE LEFT ACTIVITIES CONTINUE THROUGH GARVEY'S DELIVERY; HOWEVER, THE NEGROES ONE BY ONE ARE DRAWN OUT OF CURIOSITY TO- 
WARD THE GARVEY FOLLOWERS.) Signs: "MADISON SQUARE GARDEN . . . TONIGHT, AUGUST 2, 1920; 25,000 U.N.I.A. DELEGATES"; CROWD WAVING BANNERS-"LONG LIVE THE IRISH REPUBLIC," "IRELAND FOR THE IRISH: AFRICA FOR THE AFRICAN." Newspaper boy on the corner selling Marcus Garvey cigars and the Negro World, hawking headline: "25,000 Negroes to attend convention at Madison Square Garden; delegates to draft 'Declaration of the Rights of Negro Peoples of the World.' League of Nations null and void for Negro citizens. Black House proposed for Washington." Paper, paper! Get your Negro World!

One banner in white with black lettering: "Black Star Nurses." This has a black star in the center. Reverend George Alexander McGuire, Episcopal clergyman, with banner, "Black Madonna and Christ." This has a picture in black "African Orthodox Church," and Rev. George Alexander McGuire.

1st White Worker (STANDING ON A BOX): It is to Marx and Lenin that the worker in America must turn; we cannot, in the name of labor, hope to get sympathy and justice from management. It is the very nature of capitalism that masses must hunger while a fortunate few lounge in plenty.

1st Black Worker: We want jobs, not speeches. We didn't fight in Europe for democracy to be denied the right to work at home.

All White Workers: We don't need no scabs; black scabs. Things are bad enough without you. What are you looking for, another "Red Summer" like last year!!!

2nd Black Worker: This mill has government contracts and should hire black veterans. That's the least a man can expect after risking his life.

2nd White Worker: Going to France just made niggers sassy.

3rd White Worker: It'll take the Klan to put you in your place.

3rd Black Worker: The Klan had better keep playing games with the Southern Negroes. I know I'm armed and I don't know a self-respecting black who isn't.

4th Black Worker: You'll get another "Red Summer."

1st Black Worker: Man, I came here to work, not to socialize. 
(TRIES TO CROSS THE LINE. HE IS FELLED BY A BLOW FROM A WHITE PICKETER. AS THEY SCUFFLE, MOVEMENT SHOULD SHIFT UPSTAGE; BAND CAN BE HEARD OFFSTAGE BEFORE PARADE COMES ON STAGE LEFT; CUTS SQUARE CORNER GOING UPSTAGE CENTER; CUTS ANOTHER SQUARE CORNER HEADING LEFT AND DOWNSTAGE AND SPREADING OUT ABOUT THE RISERS, FORMING AUDIENCE. FOLLOWING BAND ARE THE BLACK STAR NURSES; FOLLOWING THEM IS THE CLERGYMAN, THEN THE AFRICAN LEGION, WHO CONTINUE ACROSS STAGE DOWNSTAGE, WITH DRAWN SABERS TO FORM AN ARCHWAY FOR MARCUS GARVEY.

\section{All (OFFSTAGE AND MARCHING ON IN CHORUS):}

Ethiopia, thou land of our Fathers,

Thou land where the gods loved to be, As storm cloud at night suddenly gathers

Our armies come rushing to thee.

We must in the fight be victorious

When swords are thrust outward to gleam;

For us will the Vic'try be glorious

When led by the red, black, and green.

Advance, advance to victory.

Let Africa be free;

Advance to meet the foe

With the might

Of the red, the black and the green.

All (AS GARVEY ENTERS):

One God, our firm endeavor,

One aim, most glorious bent,

One destiny forever,

God bless our President.

Spokesman (MOUNTING THE RISER AND ASSISTING MARCUS GARVEY, WHO WAVES TO THE CHEERING CROWD): During this devastating World War, black workers came North to fill those empty work benches; went to Europe to fight for world democracy. Forced from the South by a depression, the black man reached the North in time to get a headstart toward the developing depression in the North. When President Woodrow Wilson issued his call to arms, 400,000 Negroes answered and served in the war; black money bought $\$ 250,000,000$ worth of bonds and 
stamps. But where are the homes for the black people? And where are the jobs today for the black people? Join the Union, you're told; you're scabs. Then the Ku Klux Klan is called out to keep you from joining the Union.

Last summer after three days rioting the whole Negro district in our capital city, Washington, was practically burned down; Houston whites attacked our black soldiers from the 24th Infantry Regiment and for this 13 black soldiers were executed and 41 imprisoned for life. Is this justice for black people? Last summer will go down in history as the Bloody Summer, or some prefer the Red Summer; 26 race riots occurred in major American cities.

Who can the black man turn to when all else fails him? Not the NAACP, not the other so-called Negro leaders, but the true Messiah, the savior of the black people, none other than Marcus Garvey. (APPLAUSE AND CHEERS)

He knows the workers' plight. When he was a foreman back in Jamaica and his printers' union led a strike, wasn't he the only man who got blacklisted when the strike was over? He's seen the plight of the black worker. Didn't he help build the Panama Canal? Wasn't he a timekeeper in the banana plantations of Costa Rica and the docks of London? Didn't he work with the United Fruit Company in Ecuador, Nicaragua, Honduras, Colombia, Venezuela? He knows the plight of the black man the world over; and, united, he knows how to answer the prayers of the black masses. I give you Marcus Garvey. (CHEERS) Not a white man with a black heart, a black man with a white heart, but a black man with a black heart. (CHEERS)

Marcus Garvey: You are dazzled today by our pomp and ceremony; it is but a shadow of what has gone before in the splendid age of Africa, in the past courts of Ethiopia, Ghana, Timbuctu.

I stand before you this afternoon a proud black man, honored to be a black man, who would be nothing else in God's creation but a black man. Black men are not going to cringe before anyone but God. Now we have started to speak and I am only the forerunner of an awakened Africa that shall never go back to sleep.

When Europe was inhabited by a race of cannibals, a race of savages, naked men, heathens and pagans, Africa was peopled with a race of cultured black men, who were masters in art, science, and literature; men who were cultured and refined; men who, it was said, were like the gods. Even the great poets of old sang in beautiful sonnets of the delight it afforded the gods to be in companionship with the Ethiopians. Why then, should we lose hope? Black men, you were once great; you shall be great again. Lose 
not courage, lose not faith; go forward. The thing to do is to get organized.

A race without authority and power is a race without respect.

I lead you in this prayer:

God of the right our battles fight,

be with us as of yore; break down the barriers of might,

we reverently implore.

All (SINGING):

Guide him through life victorious,

Save him from accident,

Grant him his aims most glorious,

God bless our President.

\section{CURTAIN}

Act VI

Vietnam: Hell NO!!-1968

(ON BOARD AIRCRAFT SCHEDULED FOR COMBAT)

Corporal Willshoot: Man, I can't wait to get me some of those squinteyes. I'm going to just pick them off. Boom, one; boom, two; for days and days by the hundreds. Just watch me, I'll come home decorated with ribbons all down my chest.

Sergeant Blood: I'm itching for combat myself. You know, I've been in the army for almost thirty years. I fought at Pearl Harbor in 1941, the Second World War; served with the German Occupational Forces in 1950; fought in the Korean conflict in 1952. Now, I'm lucky to be on my way to Vietnam. I'm just naturally lucky in combat. There's something about war that makes you feel like a man.

Private Youngblood (WEEPING HYSTERICALLY): I don't want to kill nobody. Man, I'm scared. Those yellow men over there are my brothers, Viet Cong or not. I still can't see why I should be fighting in Vietnam. I don't want to fight in a hydrogen war. What is a gun besides an $\mathrm{H}$ bomb?

1st Soldier: See this gun? Those Viet Cong fight guerrilla war and I'll be ready for them. I keep an extra gun at all times.

2nd Soldier: Man, I got my razor with me. Out in the jungle, I slip up behind those Viet Cong and cut their damn throats. 
Private Coldshot: You guys are gasses. All you're going to do is get your asses shot off. One of those guerrillas will catch you in the jungle, hit you with a rice shoot and tear your asses up.

(ALL LAUGH AT THIS EXCEPT YOUNGBLOOD, WHO HOLDS HIS HEAD IN HIS HANDS. HIS BODY RETCHES AS HE WEEPS SILENTLY AND PRIVATE MALCOLM YOUNG LOOKS ON STONILY.)

Captain Ace: Attention, men!! As you know, we're heading into combat. It will be the first time in the battlefield for most of you. I expect you to conduct yourselves as soldiers at all times.

Sergeant Blood: Captain Ace, where are we going, sir? Vietnam?

Captain Ace: Sgt. Blood, my orders are sealed. I'll let you know when we reach our destination. At ease, fellows. (HE TURNS ABRUPTLY AND WALKS OUT. MURMURS START AS HE LEAVES THE CABIN.)

Private Youngblood: I'm going to die, men; I just feel it. I'm going to die. (HYSTERICAL) I'm not even going to live to see my son born. I haven't voted; I haven't had a drink in a bar. I've always been too young for life. Now, I'm going to die before I get a chance to live. I just married and I'm not even going to see my wife again. She's pregnant and I won't even see my son.

Sergeant Blood: Private Youngblood, act like a man, boy. I'm a sergeant, boy. You just stick to me. I'll make a man out of you. Just stick by me. I'll show you a thing or two about combat.

Private Coldshot: He's chicken; let him cry if he wants to. Leave him alone. He's scared. He's young and scared.

2nd Soldier: It's his duty to serve his country; he ought to be proud to defend our democratic form of government. I'm proud to take up arms, to defend my land and my people.

Private Malcolm Young: What land, nigger? (SARCASTIC) What people?

2nd Soldier: My land: America, my people; the American people. You young hotheaded fool, you ought to know that. Trying to act like that other Malcolm, your namesake. See what happened to him? 
Private Malcolm Young: America!!! Americans!!! Man, you're no American! Why, any honky that just got off the boat is an American: Polacks are Americans; Italians, every blue-eyed thing that comes out of Europe is already American. But it's like Malcolm says, if you're black, being born in America doesn't make you American. If you were, they wouldn't need those Constitutional amendments, that civil rights legislation. Nigger, you are one of those 22 million who are victims of Americans.

1st Soldier: Aw, who woke up old hothead? Don't listen to that shit again.

Private Coldshot: Nigger, I used to see you around those street corners listening to that Malcolm X, believing all that shit.

2nd Soldier: You're right, Coldshot. He let his name go to his head. His mother messed him up with that name Malcolm; that automatically made him one of those black revolutionaries.

Private Malcolm Young: As Malcolm said: "You're nothing but an ex-slave ... You didn't come here on the Mayflower. You came here on a slave ship. In chains, like a horse, or a cow, or a chicken. And you were brought here by the so-called Pilgrims, or Founding Fathers. They were the ones who brought you here."

2nd Soldier: Aw man, we don't want to hear that shit.

1st Soldier: When we heard you'd gone AWOL we were glad; I mean really glad. This outfit had some peace with you away. I'm sorry they found your ass and threw you aboard. When we get to Vietnam, well see how brave you are. You and Youngblood make a good team.

Private Malcolm Young: Man, our enemy is that honky. We have a common oppressor right at home; we don't need to be fighting no war to save no honky's skin.

Sergeant Blood: Watch yourself, boy. We'll have none of that talk on board this plane. Your country's been good to you and don't you forget it. Hell, yes, you got a right to fight for her. And just don't forget it. There'll be none of that black revolutionary stuff in this outfit.

Private Coldshot: Yeah, man, you best to forget all that Malcolm shit. You see where that kind of talk got him. 
Sergeant Blood: Yeah, boy, I'm telling you for the last time. You better watch yourself. You better listen to me and Coldshot.

Private Malcolm Young: Boy, boy. Why, you old Uncle Tom. Sgt. Blood they call you. Everywhere that honky sends you to bleed-you bleed: Korea, Germany, South Pacific, Vietnam. As Malcolm says, "You bleed for white people, but when it comes to seeing your own churches being bombed and little black girls murdered, you haven't any blood. You bleed when the white man says bleed; you bite when the white man says bite; and you bark when the white man says bark. How're you going to be non-violent in Mississippi, as violent as you were in Korea?" Just answer me that, Sgt. Blood.

Sergeant Blood: You damn right I bleed, like a man; I'm not afraid to bleed. My name is Sgt. Blood and don't you forget it. I don't make wars, I just fight them. I'm a loyal American citizen, right or wrong. That's something you boys will grow up to be one day.

Private Youngblood: I'm going to die. I just know it. I haven't been to a bar, I haven't even voted and I'm going to die.

Sergeant Blood: Get yourself together, Youngblood. You're a disgrace to this outfit. You're crying already and haven't even reached the combat zone yet.

Corporal Willshoot: Man, you think it'll really be Vietnam? I'm going to get me some of those squinteyes; one-two-three, a hundred; and I'll come home with medals all over my chest. I'll come back General Willshoot.

Private Coldshot: Man, I've told you, you going to get your ass shot off. One of those guerrillas will hit you with a rice shoot and tear your fat ass up. Willshoot's ass shot off by a Viet Cong with a rice shoot. (THEY LAUGH.)

Private Malcolm Young: Black mercenaries. Just like Malcolm said. You're nothing but mercenaries, just hired killers. And you're wasting your beautiful black blood fighting for the honkies. You've fought in every one of his wars from the revolution on down and what has it gotten you? You ought to be in the streets of America fighting for your black brothers and sisters; fighting for your black children.

Captain Ace (APPEARING-LOOKING AT HIS WATCH): All right men; we are almost there. I'll start the countdown. Fasten your parachutes and prepare for the countdown. 
Sergeant Blood: What's it going to be, Captain Ace? Where are we going? Hanoi? Saigon?

Private Malcolm Young: What the hell!!! This isn't Vietnam. We are still in the U.S.A.

Captain Ace (IGNORING COMMENTS): Ten, nine, eight ...

Private Malcolm Young: Look out your windows, niggers!! This war is at home!!!!!

Captain Ace (LOOKING AT HIS WATCH): Seven, six, five ...

All (LOOKING OUT WINDOWS-MAKING COMMENTS-"IT CAN'T BE! WHATS GOING ON??" SGT. BLOOD IS THE ONLY ONE WHO DOESN'T LOOK OUT BUT HEADS FOR THE EXIT, EAGER TO DO BATTLE.)

Sergeant Blood: What is the objective, Captain Ace??

All (LOOKING TOWARD PRIVATE MALCOLM YOUNG, ALTERNATELY ADJUSTING PARACHUTES AND LOOKING OUT THE WINDOW.)

Captain Ace: Let's get a move on, men. Four ... three ...

Private Youngblood: It can't be!! This is my home, California. What are we going to do?

Captain Ace: We're over target, men-North Oakland, California. (NOT LOOKING UP) Two ... one ... (HE REACHES FOR THE EXIT HATCH, OPENING IT.)

All: What are we going to do, Malcolm???

Private Youngblood: Malcolm, what do you say?

(MALCOLM RUSHES PAST THEM AND HEADS FOR THE CAPTAIN. YOUNGBLOOD GRABS THE SERGEANT.)

Private Malcolm Young (SHOVES THE SCREAMING CAPTAIN OUT THE HATCH): Let Captain Ace and Sgt. Blood handle this one. (HE 
HELPS THROW OUT THE SERGEANT AND CLOSES THE HATCH. HE TURNS TOWARD THE PILOT'S CABIN AND LEADS THE OTHERS TOWARD THE COCKPIT.)

Private Malcolm Young: We'll take over this damn ship and take it back to Washington where the real war is. See to the pilot. The Black Revolution is on; we'll do our dying at home.

\section{(LIGHTS )}

Acr VII

Black Revolt-1968-1970

HEADQUARTERS OF THE BLACK ARMY. GENERAL IS SEATED AT THE DESK; MASTER SGT. IS HANDLING COMMUNICATIONS, POSTING INFORMATION ON THE BLACKBOARD. THE BLACKBOARD HAS THE FOLLOWING INFORMATION:

DEFECTORS, U.S. ARMED FORCES-TWO REGIMENTS

DEACONS OF SELF-DEFENSE-BOGALUSA, LOUISIANA-ONE REGIMENT

SNCC HEADQUARTERS, ATLANTA, GEORGIA-TWO REGIMENTS BLACK PANTHER PARTY FOR SELF-DEFENSE, OAKLAND-ONE REGIMENT

BLACK PANTHER PARTY, LOUNDES COUNTY, ALABAMA-THREE REGIMENTS

US, LOS ANGELES, CALIFORNIA-ONE REGIMENT

BLACKSTONE RANGERS, CHICAGO-ONE REGIMENT

BLACK MOBILIZED WOMEN'S CORPS OF U.S.A.-TWO COMPANIES

Guerrilla Officer (IN PANTHER ATTIRE): General, you must give the word for all-out defense; there is no other hope. This limited warfare is taking my men too fast. They are being picked off one by one; slaughtered wholesale in the streets.

General (RISING, GRIMACING, CLENCHING HIS FISTS): There must be some other way than all-out warfare!!! Is there no hope for a truce? No possibility for peace talk?? What news do you have from the White House?

Guerrilla Officer: The hawk and the lovebirds have flown the coop and are back home on the range. 
General: What about the Senate? Any word?

Guerrilla Officer: There has been a Southern filibuster going on for days. They are powerless to interrupt due process of law. There is no other way but all-out war.

Woman Officer: Don't listen to him. You must hold out a little longer.

Guerrilla Officer: There is no time for holding out!! Every second is a waste of black lives.

General: We don't have the military strength for all-out war. You know that. We need trained fighters and equipment.

Guerrilla Officer: Black people are pouring into Washington by the thousands. The last news report said that all transportation facilities into Washington are jammed-bus stations, train stations, airports, freeways. Full of black people answering the call; they are ready for a showdown. Give the word. We'll mass our strength along Pennsylvania Avenue; take the White House and push the armed forces across the Potomac.

Woman Officer: General, don't do it!! The women's corps has dwindled to two companies. They're sick of fighting; sick of seeing those bleeding bodies in the street. We've been loyal. We've been in the field with you since the early days of SNCC. And, I hate to say it, but we've lost all hope. Give up!! Surrender! We can't win an all-out war and you know it!

(SHE PLACES HER HAND ON HIS ARM AND HE JERKS FREE, CONVULSIVELY.)

Guerrilla Officer: Don't listen to her! We can't let one unit stop the show. We'll use nurses and replacements for the women. (HE WALKS OVER TOWARD THE BOARD.) We have a pretty good chance if we rally all of our strength now and launch an all-out attack. True the Defectors are dropping off, but we have the Deacons, SNCC, the Panthers, US. (WALKING BACK TO THE GENERAL) What do you say?

General (HOLDING HIS HEAD, TORN BY THE WEIGHT OF THE DECISION): Give me time. I don't know. There is no other way, no other hope?

Guerrilla Officer: Precisely. And there is no time. It has to be NOW or 
NEVER!! Time is running out. My men are badly in need of reinforcement now. If you can't decide, then I'll have to make a decision of my own. (HE STORMS OUT.)

Woman Officer: Don't do it; it'll be suicide. We want to live, not die!!!

General: I don't know. God, is there no other way??

Guerrilla Officer (STORMING BACK IN A RAGE): Damn it to hell!! A whole regiment wiped out while you stand here not capable of making a decision. Do you declare war or not??

Woman Officer: Don't listen to him. That's not just a regiment; we're talking about a race!!!

(THE SERGEANT AT THE BOARD PUTS DOWN HIS CHALK. HE DRAWS HIS PISTOL UNNOTICED BY THE OTHERS, CAREFULLY AIMS AT THE WOMAN AND SHOOTS HER CALMLY. THEN HE PUTS BACK HIS PISTOL AND WAITS.)

Guerrilla Officer: Did you have to shoot her?

General: The bitch!! Look what she made me do! Listening to her shit while a whole regiment was wiped out. Bitch!! Bitch!! You killed her. Good. If only I had followed my own mind at first. Come on, man, let's go.

(THE MEN RUSH OFF THE STAGE AT STAGE LEFT; LIGHTS OFF, THEN FLICKERING RED, BLUE; MEN COME FROM BOTH DIRECTIONS ONSTAGE AND UNDER THE DARK LIGHTS WAGE A SILENT, GROTESQUE HAND-TO-HAND COMBAT. ALL FALL. THE STAGE IS COMPLETELY STILL . . . DARKNESS.)

(NO CURTAIN BETWEEN THIS AND FINAL ACT)

\author{
ACT VIII \\ Post Revolution-Third World \\ 1975 FINAL QUARTER 2OTH CENTURY
}

(LIGHTS-REDS AND BLUES, FLICKERING, HALF SHUT, VERY DIM; SOME STIRRINGS; AGAIN GROTESQUE MOVEMENTS, SLOW MOTION TO SUGGEST PASSAGE OF TIME. FLUTE AND DRUM OFFSTAGE. FAINT MUSIC. OTHERS COME ONSTAGE AND HELP 
PULL THE FALLEN TO THEIR FEET IN THE DARKNESS. THEN THE STAGE CROWDS WITH MORE PEOPLE. MORE MUSIC, PEOPLE TALKING. DANCERS DANCING.) Lights-add yellow at first half shut; brightening slowly with the movement on the stage. People in robes from the Timbuctu scene weave among the crowd; all actors assemble on stage for a finale.

Chorus (Repeating "When we going to rise up," and "umgawa, Black Power")

Reader (COMES FORTH TO THE PODIUM ON THE APRON-HE READS THE FOLLOWING POEM-"Invocation for Black People, Leaders of the Third World"):

Black people, arise!

Drop those fetters

from your feet;

throw off those raiments

of trials and war-

those binding chains

and hangmen ropes.

The world awaits your

crowning hour.

Be the thing you want to be;

be the thing

you are; get back your

golden tongues of song,

your rich, black, beautiful

style of life.

Get yourself together;

dig down far into the

fertile soil of

your soul; bring forth the

abundant fruit of your

deeply rooted tree

planted early by

the green banks of the

Nile at the golden dawn

of the human race. 
Creators of the first world, you will bring forth the Third World we crave; you, alone, know a love of man transcending those false boundaries of race, color, creed, class; your black face is the God of the Universe's looking glass.

Black people, you know the meaning of the brotherhood of man; you can look the human race in its jaundiced eye, see straight through those masks of envy, fear, cowardice, greed, lust, malice.

Black people, arise! Don the robes of your true nature; wear the naturals of your birthright; dance to the tune piped by your own soul-tuned music men.

Arise, black brother! Arise, black sister! Arise, beautiful black children of the world; go forth in love and glory; be the thing you want to be; be the thing you are!

Cast reassembles on stage in seven freeze positions corresponding with the acts. Theme music cues each representative scene to move from freeze position to downstage center for curtain call. Curtain. Actors remain in position for final curtain call. 